\title{
DIFFERENT STARCH SOURCES IN EXTRUDED DIETS FOR THE MALAYSIAN MAHSEER (Tortambroides): EFFECTS ON GROWTH, FEED UTILISATION AND TISSUE HISTOLOGY
}

\author{
SAIRATUL DAHLIANIS ISHAK ${ }^{1,3 *}$, YUS ANIZA YUSOF ${ }^{2}$, AMBOK BOLONG ABOL- \\ MUNAFI $^{1}$ AND MOHD SALLEH KAMARUDIN ${ }^{3}$
}

\begin{abstract}
${ }^{1}$ Institute of Tropical Aquaculture and Fisheries, Universiti Malaysia Terengganu, 21030 Kuala Nerus, Terengganu, Malaysia. ${ }^{2}$ Department of Process and Food Engineering, Faculty of Engineering, Universiti Putra Malaysia, 43400 Serdang, Selangor, Malaysia. ${ }^{3}$ Department of Aquaculture, Faculty of Agriculture, Universiti Putra Malaysia, 43400 Serdang, Selangor, Malaysia.
\end{abstract}

*Corresponding author: sairatul.ishak@umt.edu.my

Submitted final draft: 5 October $2020 \quad$ Accepted: 27 November $2020 \quad$ http://doi.org/10.46754/jssm.2021.08.008

\begin{abstract}
Sago (Metroxylon sagu), cassava (Manihot esculenta) and taro (Colocasia esculenta) are potential sources of carbohydrate in lieu of corn starch because of they can easily be grown as crops in Malaysia. We investigated the effects of these starch sources on the growth, feed utilisation efficiency, body composition, and liver and intestine histology in Malaysian mahseer (Tor tambroides) (Bleeker, 1854) fingerlings for 10 weeks. Results showed that different starch sources had significant effects $(P<0.05)$ on growth, feed utilisation efficiency and biometric indices. Moisture, lipid and gross energy composition of the fish carcass were also significantly different $(P<0.05)$. Generally, fish fed with corn and taro starch produced better weight gain, length gain, specific growth rate and lower feed conversion rate values. However, fish fed with corn starch showed high conversion of carbohydrate to lipid compared with taro starch. In tissue histology, T. tambroides liver hepatocytes and intestine mucosal epithelial cells were susceptible to lipid vacuolisation in different degrees when starch was included in the diet. In conclusion, our study suggests that $T$. tambroides had limited capability in utilising starch from different sources. However, taro starch might be the best candidate for full/partial replacement of corn starch in T. tambroides extruded feed.
\end{abstract}

Keywords: Fish feed, carbohydrate, starch, Tor tambroides.

Abbreviations: weight gain (WG), length gain (LG), feed intake (FI), specific growth rate (SGR), feeding conversion ratio (FCR), protein efficiency ratio (PER), hepato-somatic index (HSI), viscero-somatic index (VSI), intra-peritoneal fat ratio (IPF)

\section{Introduction}

Starch inclusion assists the extrusion process for better particle binding and expansion (Rosentrater et al., 2009; Hilton et al., 1981). It is also reported that carbohydrate in starch form for dietary inclusion is better than other raw forms of pulses, oilseed cakes, leaf extracts and plant meals, which have high anti-nutrient compounds and non-starch polysaccharides that must first be broken down (Alonso et al., 2000; Ghavidel \& Prakash, 2007; Rathod \& Annapure, 2016; Gatlin et al., 2007). In addition, starch gelatinisation will also improve pellet durability, increase expansion ratio and buoyancy, reduce fines, sterilises feed from microbes and toxic compounds, and improve digestibility (Bureau et al., 2002; De Silva \& Anderson, 1994; Kannadhason et al., 2011; Sørensen, 2012). Furthermore, an inclusion of digestible starch as exogenous glucose source will spare the use of essential amino acids in gluconeogenesis, thus promoting the protein-sparing effect (NRC, 2011; De Silva \& Anderson, 1994; Kamalam et al., 2017).

Fish species of different feeding habits have various anatomical and functional differences, where omnivorous and herbivorous fish can efficiently utilise dietary starch, unlike carnivorous fish (De Silva \& Anderson, 1995; Enes et al., 2011; Hardy, 2002; Krogdahl et al., 
2005; Wilson, 1994). Specific $\alpha$-amylase activity has been shown to be influenced by feeding habits and its presence in the digestive tract of carnivorous fishes enables them to digest dietary starch components by weaning (Al-Tameemi et al., 2010; Drewe et al., 2004). Inclusion of starch in diet also directly affects faeces quality, where it will increase the particle size of faeces, therefore allowing aquaculture waste to be easily removed (Keramat-Amirkolaie, 2013). The digestibility of starch in fish varies among species and it is reported that omnivorous fish can derive a high amount of energy from modified starch (Hardy \& Barrows, 2003). Various studies on cultured fish have shown that it improves digestibility, which leads to better results in growth (Sørensen et al., 2002; Cho et al., 2006; Adamidou et al., 2009). Work has been done in affirming the feeding behaviour of the Tor species of omnivorous fish (Tan, 1980; Islam \& Tanaka, 2007). In T. tambroides, the optimal dietary carbohydrate requirement is reported to be $23.44 \%$ of corn starch inclusion (Ishak et al., 2016).

In light of increasing global aqua feed cost, this study will explore the usage of domestic plant crops in fish feed in support of the local industry and lessen the dependency on imported ingredients. The aqua feed industry has been actively involved in exploring the use of plantbased ingredients to replace expensive animalbased components, such as fishmeal and fish oil, in order to maximise its carbohydrate contents as an energy source to spare protein, reduce nutrient-loading waste into the environment, and also reduce feed production cost (Gatlin et al., 2007; Trushenski et al., 2006). Starchrich agricultural products or by-products (barley, corn, canola, oat, pea, soybean, sunflower and wheat) are excellent potential carbohydrate sources for aqua feeds they are cheap and available in abundance (Arnesen \& Krogdahl, 1993; FAO, 2017). As such, three locally available starch sources in Malaysia cassava (Manihot esculenta), sago (Metroxylon sagu), and taro (Colocasia esculenta) - may be potential substitutes for corn starch in the production of extruded-floating and slow- sinking aqua feeds based on their agricultural feasibility in Malaysia (Abd-Aziz, 2002; DOA, 2012; FAO, 2017; Ferraro et al., 2016). Several studies have been reported on the use of these starch sources in producing aqua feeds.

Cassava has been incorporated in the feed for Cyprinus carpio (Ufodike \& Matty, 1983), Oreochromis niloticus (Cavalheiro et al., 2007; Gabriel et al., 2007; Kannadhason et al., 2009), Pangasius sp. (Hung et al., 2003), Salmo salar (Ah-Hen et al., 2014), Lates calcarifer (Glencross et al., 2012) and T. tambroides (Ismail et al., 2012; Umar et al., 2013). Sago starch has been successfully used as a carrageenan replacement in the feed for penaeid shrimps (Pascual \& Sumalangcay, 1981; Murai et al., 1981; Piedad-Pascual et al., 1978). It has also been incorporated as an ingredient in the feed for Mystus nemurus (Hamid et al., 2011), tilapia (Kamarudin et al., 2016) and $T$. tambroides (Umar et al., 2013). Meanwhile, taro is easily cultivated as a staple in the AsiaPacific region. It is, however, uncommon to find commercial-scale industrial starch processing from taro (Onwueme, 1999; Deo et al., 2009). Nonetheless, usage of lab prepared taro starch has been shown to have good potential in the preparation of $T$. tambroides feed (De Cruz et al., 2015).

This study assessed the nutritional value of selected starch sources incorporated in the diet of T. tambroides. For this purpose, their effects on growth, feed utilisation efficiency, body composition, nutrient retention, and liver and intestinal histomorphology are evaluated. It is our hope that the results of this study will provide new opportunities for commercial production of local starch sources in aqua feed, and also to produce aqua feed tailored to the dietary requirements of the mahseer.

\section{Materials and methods}

\section{Experimental diets}

The nutrient composition of four starch sources (corn, cassava, sago, taro) was predetermined and shown in Table 1. Commercially available 
food-grade corn starch, cassava starch and sago starch were purchased from a local supplier (Yummie Bakery Sdn Bhd, Malaysia). Fresh taro corms were purchased from a local market in Selangor, Malaysia, and its starch was prepared following the method described by De Cruz et al. (2015).

Experimental diets used for this feeding trial were formulated based on the dietary requirements of the Malaysian mahseer at 40.00 $\%$ protein and $23.44 \%$ carbohydrate according to Ishak et al. (2016). The dietary lipid (per cent as fed basis) was kept below $11 \%$ as the growth of $T$. tambroides had been reportedly affected above that level (Ng \& Andin, 2011; Ishak et al., 2016). The feed and nutrient composition of the experimental diets are shown in Table 2.

\section{Feeding Trial and Sampling}

Wild T. tambroides fingerlings were obtained in Kelantan, Malaysia, and acclimatised for three weeks in a one-tonne fibreglass tank at the Wet Laboratory in the Department of Aquaculture, Universiti Putra Malaysia. During this period, the fingerlings were graded based on size. Graded fish were then fed ad libitum a $32 \%$ crude protein commercial tilapia starter feed (StarFeed (M) Sdn Bhd, Malaysia) and were observed to readily accept the commercial diet. Upon acclimatisation, 12 sets of $60 \mathrm{~L}$ glass aquaria $(38 \mathrm{~cm} \times 75 \mathrm{~cm} \times 35 \mathrm{~cm})$ were randomly stocked with 20 fish each (initial body weight $1.27 \pm 0.01$ $\mathrm{g}$; initial total length $5.20 \pm 0.02 \mathrm{~cm})$. Each aquarium was supplied with continuous aeration and up to $25 \%$ water change was done weekly using dechlorinated municipal water. Water temperature, $\mathrm{pH}$ and dissolved oxygen were maintained at $26.0 \pm 1.0^{\circ} \mathrm{C}, 6.5 \pm 0.2$ and $5.0 \pm 0.5$ $\mathrm{mg} \mathrm{l}^{-1}$, respectively. Fish were fed experimental diets in triplicates daily at $4 \%$ body weight twice a day ( $8 \mathrm{am}$ and $5 \mathrm{pm}$ ) for 10 weeks. Body weight and total length were recorded bi-weekly throughout the feeding trial, whereas mortality was recorded daily when applicable. The growth parameters used are weight gain (WG), length gain (LG), and specific growth rate (SGR) were calculated using Equations 1, 2 and 3:

$$
\begin{aligned}
& \mathrm{WG}(\%)=100 \times(\text { final body weight-initial } \\
& \text { body weight)/initial body } \\
& \text { weight } \\
& \mathrm{LG}(\%)=100 \times(\text { final body length }- \text { initial } \\
& \text { body length)/initial body } \\
& \text { length }
\end{aligned}
$$

The amount of feed throughout the trial was recorded to determine the feeding efficiencies which are feed intake (FI), feeding conversion ratio (FCR) and protein efficiency ratio (PER), using Equations 4, 5 and 6 as below.

$$
\begin{aligned}
\mathrm{FI}=\quad & \begin{array}{l}
\text { weight of feed given until treatment } \\
\text { ended/total of fish per treatment }
\end{array} \\
\mathrm{FCR}= & \begin{array}{l}
\text { weight of feed consumed/body } \\
\text { weight gain }
\end{array}
\end{aligned}
$$

Table 1: Proximate composition (\% as fed basis) of the four starch sources

\begin{tabular}{lcccc}
\hline & \multicolumn{4}{c}{ Starch source } \\
\cline { 2 - 5 } & Corn & Cassava & Sago & Taro \\
\hline Proximate composition & 11.50 & 15.40 & 14.80 & 8.00 \\
Moisture & 0 & 0 & 0 & 5.80 \\
Protein & 0 & 0 & 0 & 0.79 \\
Lipid & 88.50 & 84.60 & 85.20 & 85.41 \\
Carbohydrate & 14.84 & 14.59 & 14.44 & 15.45 \\
Gross energy $\left(\mathrm{kJ} \mathrm{g}^{-1}\right)$ & & &
\end{tabular}


Table 2: Feed ingredient and proximate composition ( $\%$ as fed basis) of the four experimental diets

\begin{tabular}{lcccc}
\hline & \multicolumn{4}{c}{ Starch Source } \\
\hline & Corn & Cassava & Sago & Taro \\
\hline Feed Ingredient & & & & \\
Fishmeal $^{\text {a }}$ & 69.00 & 69.00 & 69.00 & 69.00 \\
Vegetable oil $^{\mathrm{b}}$ & 5.56 & 5.56 & 5.56 & 5.56 \\
Vitamin premix $^{\mathrm{c}}$ & 1.00 & 1.00 & 1.00 & 1.00 \\
Mineral premix $^{\mathrm{d}}$ & 1.00 & 1.00 & 1.00 & 1.00 \\
Corn starch & 23.44 & 0 & 0 & 0 \\
Cassava starch & 0 & 23.44 & 0 & 0 \\
Sago starch & 0 & 0 & 23.44 & 0 \\
Taro starch & 0 & 0 & 0 & 23.44 \\
& & & & \\
Proximate composition & & & & \\
Moisture & 8.48 & 6.96 & 7.09 & 6.42 \\
Protein & 40.48 & 39.89 & 39.28 & 41.27 \\
Lipid & 8.18 & 7.31 & 8.67 & 7.46 \\
Ash & 19.60 & 17.25 & 18.63 & 18.20 \\
Fibre & 0.92 & 0.48 & 0.87 & 1.33 \\
Carbohydrate & 23.26 & 28.59 & 26.33 & 26.65 \\
Gross energy (kJg-1) & 17.32 & 17.91 & 17.50 & 17.91 \\
\hline
\end{tabular}

a Fishmeal with $59 \%$ crude protein.

b Mixture of canola and sunflower oil (Naturel ${ }^{\mathrm{TM}}$ ).

c Vitamin premix: (g kg premix ${ }^{-1}$ ); ascorbic acid, 45; myoinositol, 5; choline chloride, 75; niacin, 4.5; riboflavin, 1; pyridoxine, 1; thiaminmononitrate, 0.92; Ca-pantothenate, 3; retinyl acetate, 0.6; cholecalciferol, 0.083; vitamin $\mathrm{K}$ menadione, 1.67 ; $\alpha$-tocopheryl acetate $\left(500 \mathrm{IU} \mathrm{g}^{-1}\right.$ ), 8; biotin, 0.02 ; folic acid, 0.09 ; vitamin B12, 0.001 ; cellulose, 845.11.

d Mineral premix (g kg premix ${ }^{-1}$ ): KCL, 90; KI, 0.04; $\mathrm{CaHPO}_{4} .2 \mathrm{H}_{2} \mathrm{O}, 500 ; \mathrm{NaCl}, 40 ; \mathrm{CuSO}_{4} .5 \mathrm{H}_{2} \mathrm{O}, 3$; $\mathrm{ZnSO}_{4} \cdot 7 \mathrm{H}_{2} \mathrm{O}, 4 ; \mathrm{CoSO}_{4}, 0.02 ; \mathrm{FeSO}_{4} 7 \mathrm{H}_{2} \mathrm{O}, 20 ; \mathrm{MnSO}_{4} \cdot \mathrm{H}_{2} \mathrm{O}, 3 ; \mathrm{CaCo}_{3}, 215 ; \mathrm{MgOH}, 124 ; \mathrm{Na}_{2} \mathrm{SeO}_{3}, 0.03$; $\mathrm{NaF}, 1$.

e Crude carbohydrate $=100$-(moisture + crude protein + crude lipid + ash $)$

PER $=$ body weight gain/protein intake

At the end of the feeding trial, 10 fishes from each tank were randomly selected and sacrificed following anesthetisation with NIKATransmore ${ }^{\circledR}$ fish stabilizer. Internal organs were removed and weighed, while intraperitoneal fat was obtained by collecting all the fat from the abdominal cavity, as well as those separated from the viscera. Hepatosomatic index (HSI), viscerosomatic index (VSI) and intraperitoneal fat ratio (IPF) were calculated using Equations 7,8 and 9:
(6) $\operatorname{HSI}(\%)=100 \times$ liver weight $/$ total body weight)

$\operatorname{VSI}(\%)=100 \times($ viscera weight $/$ total body weight)

$\operatorname{IPF}(\%)=100 \times($ collected fat weight $/$ total body weight)

Subsequently, extracted livers and intestines ( $n=9$ each treatment, for each respective tissue) were fixed for histological study. The remaining fish bodies without internal organs $(n=10$ each replicate), which from now on would be referred 
to as fish carcass, was freeze-dried for proximate analysis.

\section{Proximate Analysis}

All samples (ingredients, diets, fish carcass for initial analysis and fish carcass from treatments) were analysed for protein, lipid, fibre, ash, moisture and gross energy content following their respective methods (AOAC, 1995). Protein content was estimated using the 2400 Kjeltec Analyzer Unit (FOSS, Denmark) following digestion in sulphuric acid at $380{ }^{\circ} \mathrm{C}$ for $60 \mathrm{~min}$. Lipid content was analysed using the Foss Tecator Lipid Analyzer (FOSS, Denmark). Defatted samples were then analysed using the Fibertec Cold Extractor unit, followed by acid and alkaline digestion using the Fibertec Hot Extractor Foss Tecator (FOSS, Denmark) to determine crude fibre content. Moisture content was determined by the AD-4715 infrared moisture determination balance (A\&D Company, Japan). Ash content was estimated according to the protocols stated by AOAC (1995). Finally, gross energy was determined using an AC-350 bomb calorimeter (LECO, USA). From these data, the following nutrient retention values were calculated according to Equations 9, 10, 11 and 12.

Protein retention value $(\%)=100 \times[$ (final body weight $\times$ final fish carcass protein)-(initial body weight $\times$ initial fish carcass protein)]/ (total dry protein intake)

Lipid retention value $(\%)=100 \times[($ final body weight $\times$ final fish carcass lipid)-(initial body weight $\times$ initial fish carcass lipid)]/(total dry lipid intake)

Carbohydrate retention value $(\%)=100 \times[($ final body weight $\times$ final fish carcass carbohydrate)(initial body weight $\times$ initial fish carcass carbohydrate)]/(total dry carbohydrate intake)

Energy retention value $(\%)=100 \times[$ (final body weight $\times$ final fish carcass energy) (initial body weight $\times$ initial fish carcass energy)]/(total dry energy intake)

\section{Histology}

Procedures for haematoxylin and eosin staining were carried out according to Luna (1968). Excess fat was trimmed from the liver and intestines before the samples were immediately fixed in Bouin's solution for $24 \mathrm{~h}$. Subsequently, fixed samples were stored in $70 \%$ ethanol. Tissues were next dehydrated in a series of graded ethanol as in standard histological protocol and embedded in paraffin wax. Embedded tissues were sectioned at a thickness of $5 \mu \mathrm{m}$ before being stained with haematoxylin and eosin, and mounted in DPX. Slides were examined under a light microscope (Carl Zeiss GmbH, Germany).

\section{Statistical Analysis}

All data values were reported as mean \pm standard error $(n=3)$ and were subjected to oneway analysis of variance (one-way ANOVA). Differences between means were tested using Duncan's New Multiple Range Test at $P<0.05$. Percentage data were arcsine transformed before statistical analysis.

\section{Results}

Dietary starch source had significant effects $(P<0.05)$ on growth performance (WG, LG, SGR), feed efficiency (FCR, PER), HSI and IPF of mahseer fingerlings (Table 3). Fish fed corn starch and taro starch recorded significantly higher $(P<0.05) \mathrm{WG}$ and also had significantly lower $(P<0.05)$ FCR compared to those fed with other starches. Fish fed with corn starch had a higher LG $(P<0.05)$ than fish fed with sago starch. The FI for fish fed with cassava starch was the lowest $(\mathrm{P}<0.05)$ among treatments. Subsequently, PER for fish fed with corn starch was the highest, while fish fed cassava starch had the lowest PER. No significant differences $(P>0.05)$ were found in survival among treatments. HSI and IPF were significantly affected $(P<0.05)$ by dietary starch sources. Fish fed with corn starch had the highest IPF and HSI. No significant differences $(P>0.05)$ were observed for VSI in all treatments. 
It was also observed that body moisture, lipid and gross energy content of the fish were significantly affected $(P<0.05)$ by dietary starch sources (Table 4). Fish fed with corn starch had the lowest body moisture and highest lipid content. In contrast, fish fed with sago starch had the highest gross energy content, although it was not significantly different $(P>0.05)$ than that of fish fed with corn starch. Consequently, there was no significant effect $(P>0.05)$ of starch source observed for fish body protein, ash, fibre and carbohydrate. Results also showed that starch source significantly affected $(P<0.05)$ all nutrient retention values (Table 5$)$. Fish fed with corn starch had the highest $(P<0.05)$ protein, lipid and energy retention. In general, the carbohydrate retention was low in all fish groups. However, fish fed with corn and sago starch had significantly higher $(P<0.05)$ carbohydrate retention compared to other treatments. Fish fed with cassava starch achieved the lowest values in the retention of all nutrients.

Histological examination of $T$. tambroides liver hepatocytes found a condition of steatosis - accumulation of lipid vacuoles in liver - in all diet treatments (Figure 1). Minor steatosis with small lipid vacuoles was observed in fish fed with corn starch compared to others (Figure 1A). Both fish fed with sago and taro starches developed major steatosis and larger sizes of lipid vacuoles in their liver (Figure 1C, 1D).

Table 3: Growth, feed utilisation and body indices of mahseer fingerlings fed with experimental starch diets for 10 weeks

\begin{tabular}{lcccc}
\hline \multicolumn{1}{c}{ Parameter } & Corn & Cassava & Sago & Taro \\
\hline Survival (\%) & $91.67 \pm 4.41$ & $91.67 \pm 1.67$ & $91.67 \pm 6.00$ & $93.33 \pm 4.41$ \\
& & & & \\
Body Weight & & & & \\
Initial (g) & $1.25 \pm 0.01$ & $1.24 \pm 0.03$ & $1.29 \pm 0.02$ & $1.28 \pm 0.01$ \\
Final (g) & $2.69 \pm 0.02^{\mathrm{a}}$ & $1.99 \pm 0.10^{\mathrm{c}}$ & $2.28 \pm 0.09^{\mathrm{b}}$ & $2.51 \pm 0.08^{\mathrm{ab}}$ \\
WG (\%) & $114.12 \pm 0.56^{\mathrm{a}}$ & $62.17 \pm 9.40^{\mathrm{b}}$ & $77.45 \pm 4.90^{\mathrm{b}}$ & $96.36 \pm 4.14^{\mathrm{a}}$ \\
& & & & \\
Total Length & & & \\
Initial (cm) & & & & \\
Final (cm) & $5.17 \pm 0.02$ & $5.14 \pm 0.04$ & $5.25 \pm 0.01$ & $5.22 \pm 0.03$ \\
LG (\%) & $6.18 \pm 0.07$ & $5.89 \pm 0.15$ & $5.90 \pm 0.06$ & $6.12 \pm 0.09$ \\
& $19.73 \pm 1.87^{\mathrm{a}}$ & $14.71 \pm 2.85^{\mathrm{ab}}$ & $12.49 \pm 1.20^{\mathrm{b}}$ & $17.20 \pm 1.14^{\mathrm{ab}}$ \\
FI & & & \\
SGR & & & $3.88 \pm 0.05^{\mathrm{a}}$ \\
FCR & $3.91 \pm 0.07^{\mathrm{a}}$ & $3.03 \pm 0.26^{\mathrm{b}}$ & $3.83 \pm 0.32^{\mathrm{a}}$ & $0.96 \pm 0.03^{\mathrm{ab}}$ \\
PER & $1.09 \pm 0.00^{\mathrm{a}}$ & $0.69 \pm 0.08^{\mathrm{c}}$ & $0.82 \pm 0.04^{\mathrm{bc}}$ & $3.17 \pm 0.14^{\mathrm{b}}$ \\
& $2.73 \pm 0.04^{\mathrm{b}}$ & $4.10 \pm 0.26^{\mathrm{a}}$ & $3.84 \pm 0.07^{\mathrm{a}}$ & $0.77 \pm 0.03^{\mathrm{ab}}$ \\
HSI & $0.90 \pm 0.01^{\mathrm{a}}$ & $0.62 \pm 0.04^{\mathrm{b}}$ & $0.79 \pm 0.11^{\mathrm{ab}}$ & \\
VSI & & & & $1.59 \pm 0.18^{\mathrm{b}}$ \\
IPF (\%) & $2.05 \pm 0.06^{\mathrm{a}}$ & $1.48 \pm 0.01^{\mathrm{b}}$ & $1.51 \pm 0.09^{\mathrm{b}}$ & $2.52 \pm 0.14$ \\
\hline & $2.33 \pm 0.05$ & $2.56 \pm 0.11$ & $2.62 \pm 0.19$ & $0.92 \pm 0.07^{\mathrm{b}}$ \\
\hline
\end{tabular}

Means \pm standard error (SE) within a row and followed by different superscripts are significantly different at $P<0.05$. 
Table 4: Body proximate composition (\% wet weight) of mahseer fingerlings fed experimental starch diets after 10 weeks

\begin{tabular}{lccccc}
\hline & \multicolumn{5}{c}{ Starch Source } \\
\cline { 2 - 6 } & Initial & Corn & Cassava & Sago & Taro \\
\hline Proximate composition & & & & & \\
Moisture & 85.23 & $72.78 \pm 0.94^{\mathrm{b}}$ & $77.81 \pm 0.88^{\mathrm{a}}$ & $75.50 \pm 0.97^{\mathrm{ab}}$ & $76.49 \pm 0.40^{\mathrm{a}}$ \\
Protein & 8.29 & $12.07 \pm 0.19$ & $10.47 \pm 1.38$ & $11.16 \pm 0.58$ & $11.08 \pm 0.02$ \\
Lipid & 1.53 & $10.60 \pm 0.90^{\mathrm{a}}$ & $7.50 \pm 0.67^{\mathrm{b}}$ & $8.44 \pm 0.70^{\mathrm{ab}}$ & $7.62 \pm 0.36^{\mathrm{b}}$ \\
Ash & 2.09 & $2.47 \pm 0.12$ & $2.25 \pm 0.04$ & $2.29 \pm 0.13$ & $2.44 \pm 0.12$ \\
Fibre & 0.13 & $0.04 \pm 0.03$ & $0.10 \pm 0.02$ & $0.05 \pm 0.00$ & $0.04 \pm 0.00$ \\
Carbohydrate & 2.86 & $2.07 \pm 0.06$ & $1.98 \pm 0.24$ & $2.61 \pm 0.63$ & $2.36 \pm 0.07$ \\
Gross energy $\left(\mathrm{kJ} \mathrm{g}^{-1}\right)$ & 22.48 & $25.77 \pm 0.13^{\mathrm{a}}$ & $24.84 \pm 0.03^{\mathrm{b}}$ & $25.79 \pm 0.26^{\mathrm{a}}$ & $24.75 \pm 0.10^{\mathrm{b}}$ \\
\hline
\end{tabular}

Means \pm standard error (SE) within a row and followed by different superscripts are significantly different at $P<0.05$

Table 5: Dietary nutrient retention (\%) of mahseer fingerlings fed experimental starch diets after 10 weeks

\begin{tabular}{lcccc}
\hline & \multicolumn{4}{c}{ Starch Source } \\
\cline { 2 - 5 } & Corn & Cassava & Sago & Taro \\
\hline Nutrient retention (\%) & & & & \\
Protein & $13.91 \pm 0.18^{\mathrm{a}}$ & $8.66 \pm 0.21^{\mathrm{c}}$ & $11.26 \pm 1.08^{\mathrm{b}}$ & $10.72 \pm 0.35^{\mathrm{b}}$ \\
Lipid & $83.08 \pm 1.09^{\mathrm{a}}$ & $68.39 \pm 1.78^{\mathrm{c}}$ & $77.65 \pm 3.73^{\mathrm{b}}$ & $72.85 \pm 1.63^{\mathrm{bc}}$ \\
Carbohydrate & $3.19 \pm 0.05^{\mathrm{a}}$ & $1.45 \pm 0.18^{\mathrm{c}}$ & $3.84 \pm 0.45^{\mathrm{a}}$ & $2.51 \pm 0.12^{\mathrm{b}}$ \\
Energy & $60.59 \pm 0.78^{\mathrm{a}}$ & $42.80 \pm 1.50^{\mathrm{c}}$ & $44.68 \pm 1.24^{\mathrm{c}}$ & $51.61 \pm 1.89^{\mathrm{b}}$ \\
\hline
\end{tabular}

Means \pm standard error (SE) within a row and followed by different superscripts are significantly different at $P<0.05$

However, fish fed with sago starch displayed obvious reduction of prominent nucleus, indicating degenerated hepatocytes with signs of hypertrophy (Figure 1C). Observation of intestines showed that fish fed with corn starch had thicker submucosa and slightly decreased villi length compared to other treatments, but did not display enteritis or intestinal inflammation (Figure 2A). In comparison, mucosal epithelial cells in fish fed with corn and taro starches were observed to contain more intracytoplasmic lipid vacuoles (Figure 2A, 2D). Leucocytes appeared to be fewer in fish fed with cassava starch (Figure 2B). 

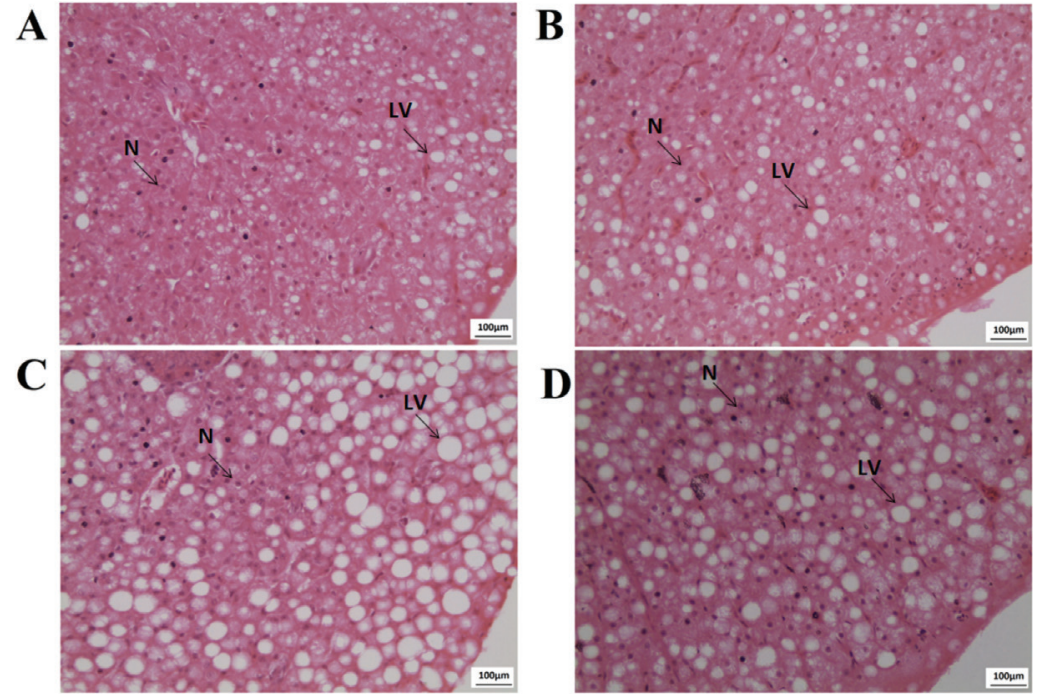

Figure 1: Histology of liver hepatocytes of mahseer fingerlings fed with experimental diets for 10 weeks: (A) fish fed with corn starch showing minor steatosis with small LVs; (B) fish fed with cassava starch showing steatosis with small LVs; (C) fish fed with sago starch showing degenerated hepatocytes with signs of hypertrophy; (D) fish fed with taro starch, showing major steatosis and large LVs. Magnification $\times 10$; scale bar $=100 \mu \mathrm{m} ; \mathrm{N}$, nucleus; LV, lipid vacuole
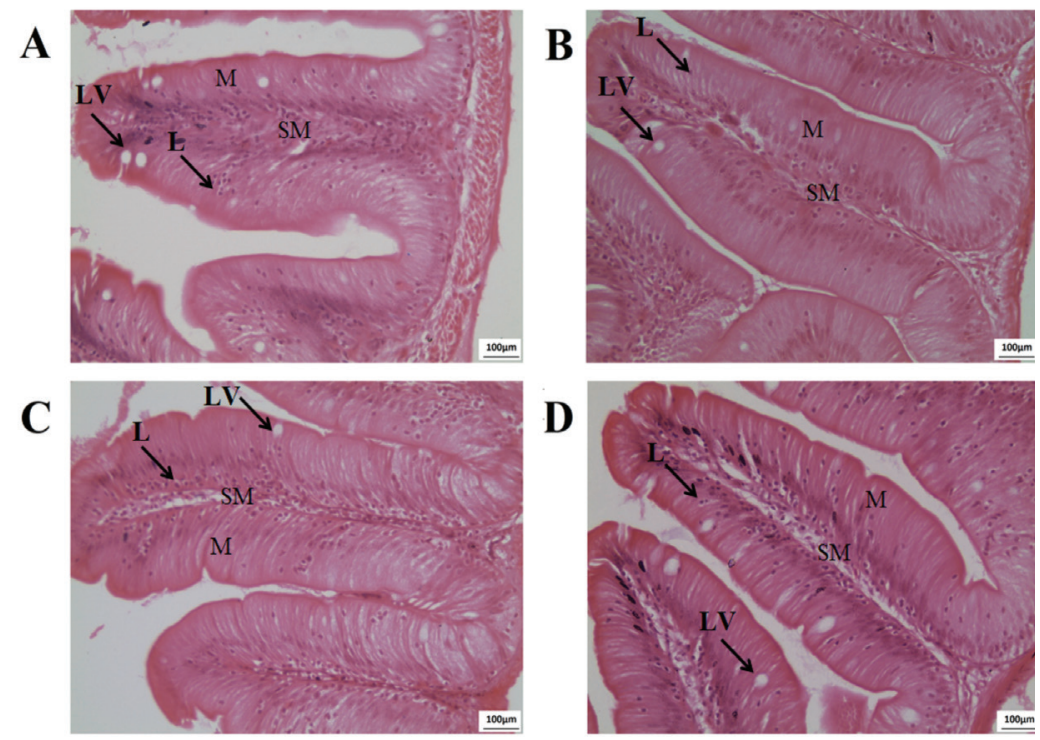

Figure 2: Histology of mahseer fingerling intestines. (A) fish fed with corn starch; (B) fish fed with cassava starch; (C) fish fed with sago starch; (D) fish fed with taro starch. Magnification $\times 10$; scale bar = $100 \mu \mathrm{m} ; \mathrm{M}$, mucosa cells; SM, submucosa; LV, lipid vacuole; L, leucocyte 


\section{Discussion}

Starch comprised two major complex polysaccharides; amylose and amylopectin. Amylose had longer linear $\alpha$-D- $(1,4)$ glucan chains, whereas amylopectin was made up of a larger branched molecule containing both $\alpha$-D- $(1,4)$ and $\alpha$-D- $(1,6)$ chains with higher molecular weight (Ball et al., 1996; FAO, 1998; Keetels et al., 1996; Manners, 1989; Pfister \& Zeeman, 2016). Starch ingested in fish would be hydrolysed by $\alpha$-amylase, breaking down the $\alpha$-D- $(1,4)$ glycosidic bonds of starch into its constituent sugar and oligosaccharides in the gastrointestinal tract (De Silva \& Anderson, 1995; Kamalam et al., 2016; NRC, 2011). As such, omnivorous and herbivorous fish that had this capability could readily accept the dietary inclusion of starch and exhibited a carbohydrate protein-sparing effect compared with their carnivorous counterparts (German et al., 2010; Hemre et al., 2002).

In this study, T. tambroides fingerlings were observed to readily accept all experimental diets with fish that had been fed sago and taro starches having similar feed intake to fish fed with corn starch. However, lower intake of cassava starch diet indicated that the mahseer could become selective towards starch sources in its diet. Better FCR values of fish fed with corn and taro diets were observed to be within the range reported for this species (Misieng et al., 2011; Ismail et al., 2012), compared to the higher FCR values of fish fed with cassava and taro diets. In comparison, the Himalayan mahseer (Tor pitutora) and Indian mahseer (Tor tor) had been reported to have better FCR range of 2.0 and lower (Islam \& Tanaka, 2004; Lone \& Lone, 2014). It was reported that starches from different sources had different morphology, and different amylose to amylopectin ratio based on their botanical origins (Singh et al., 2007). Different physiological responses by T. tambroides towards dietary treatments were probably due to this dissimilarity in nature, and the complexity of the starches from different plant sources (Gatlin III et al., 2007; Russell et al., 2001).
In this study, fish fed with corn and taro starches showed better growth and feed utilisation than the counterparts fed with cassava and sago starches. Response to different dietary starch sources was reported to be species-dependent. For example, the gilthead seabream (Sparus aurata) showed better growth performance when fed diets containing wheat or barley than corn or rye (Couto et al., 2016; Venou et al., 2003), whereas bagrid catfish (Mystus nemurus) performed better with diets containing rice or corn, compared with diets with dextrin or sago (Hamid et al., 2011). The mirror carp (Cyprinus carpio) responded better to the inclusion of rice in its diet compared to cassava (Ufodike \& Matty, 1983). In contrast, no significant difference was observed in the growth of European sea bass (Dicentrarchus labrax) and Atlantic salmon (Salmo salar) fed with different starch sources (Couto et al., 2017; Russell et al., 2001; Storebakken et al., 2000).

Starch gelatinisation and glucose metabolism, however, were not investigated in this study, but other studies had shown that they might also affect growth. Different starch sources were proven to have different gelatinisation rates in formulated $T$. tambroides feed during extrusion and, thus, could influence fish digestibility (De Cruz et al., 2015; Umar et al., 2013). The jundiá catfish (Rhamdia quelen) and Nile tilapia (Oreochromis niloticus) displayed differences in starch digestibility when fed different starch sources (Do Carmo GominhoRosa, 2015). Wu et al. (2007) reported that yellowfin seabream (Sparus latus) responded better to raw starch than pregelatinised starch in its diet. In comparison, when fed either gelatinised wheat, corn or oats, S. salar was shown to have similar growth although its glucose absorption was affected by parr-smolt transformation (Hemre \& Hansen, 1998). The largemouth bass (Micropterus salmoides) showed better growth when fed with corn and pea starches, but fish fed with cassava and wheat starches were observed to develop better hepatic glycogen levels (Song et al., 2018). 
In this study, T. tambroides fed with corn starch had the highest HSI and IPF ratios compared with cassava, sago and taro. It could be presumed that the excess energy from the dietary carbohydrate was converted into lipid and deposited as glycogen in the liver, resulting in an increase of HSI as those observed by earlier studies (Hemre et al., 2002; Mohanta et al., 2007; Wu et al., 2015). Subsequently, D. labrax fed with fishmeal-based diets including corn starch had higher HSI compared with those fed diets of fishmeal replaced by plant proteins, such as soybean meal, wheat meal and corn gluten (Guerreiro et al., 2015). When fed with a carbohydrate incorporated diet, the hybrid striped bass (Morone chrysops $\times$ M. saxatilis) also attained higher HSI compared to those fed a starch-free and high lipid diet, although fish fed with high lipid diet had higher IPF (Wu et al., 2015). In another study, T. tambroides showed an increased IPF with the increase of dietary lipid (Ng \& Andin, 2011). This might indicate that a diet containing corn starch was easily digested by T. tambroides, although the diet had a slightly lower gross energy content at $17.32 \mathrm{~kJ}$ $\mathrm{g}^{-1}$ compared to other diets.

Results also showed that body moisture, lipid and energy retention of T. tambroides were affected when given different starch sources. Similarly, moisture and lipid compositions in hybrid striped bass and $C$. carpio were affected with different dietary corn starch treatments (Wu et al., 2015; Ufodike \& Matty, 1983). In contrast, the body composition of S.aurata remained unaffected when fed corn, barley, wheat or rye (Couto et al., 2016). The PER and protein retention of mahseer in the present study indicated a protein-sparing effect by different starch sources. The protein-sparing effect was not observed when different dietary carbohydrate levels of corn starch were tested in an earlier study (Ishak et al., 2016). The high IPF ratio, lipid retention and body lipid in T. tambroides fed with corn starch indicated that the starch could induce a higher de novo conversion of carbohydrate to lipid compared to other starches.
All liver samples of the T. tambroides exhibited steatosis of varying degree. However, fish fed with sago starch undertook the most negative effects as indicated by hepatocyte degeneration and major steatosis. Similar results had been reported in the hepatocytes of mahseers fed with diets containing different palm oil to sunflower oil ratios (Ramezani Fard et al., 2014). Consequently, it had been observed that $T$. tambroides was susceptible to hepatic steatosis when given high-energy diets (Ramezani-Fard \& Kamarudin, 2012; Ramezani Fard et al., 2014). Lipid vacuolisation in hepatocytes and mucosal epithelial cells were present in all liver and intestine samples. A similar observation had been reported in hepatocytes of Atlantic salmon with the dietary inclusion of plant meals, whereas no lipid vacuoles were found in fish fed with fishmeal only (Gu et al., 2014). Histological observation of the intestines also observed that lipid vacuolisation occurred more in T. tambroides fed with corn and taro starches. In contrast, intestinal morphology of $S$. salar and $S$. aurata was unaffected when fed different types of dietary carbohydrates (Couto et al., 2016; Storebakken et al., 2000). Rainbow trout (Oncorhynchus mykiss) fed a high inclusion $(50 \%)$ of yellow lupin kernel meal showed a lower occurrence of lipid vacuoles in hepatocytes compared to those fed a lupin-free diet (Glencross et al., 2004). Slightly shorter mucosal folds and thicker submucosa were observed in fish fed with corn starch compared to other dietary treatments. This indicated that the inclusion of starches derived from plants could influence the formation of lipid vacuoles in T. tambroides liver hepatocytes and intestine mucosal epithelial cells.

\section{Conclusion}

The inclusion of different starch sources in experimental diets could affect growth, feed utilisation efficiency, body composition and nutrient retention, besides influencing liver and intestinal histomorphology of $T$. tambroides fingerlings. The overall performance of fish fed with taro starch was comparable to the 
performance of a corn starch diet. In general, T. tambroides was not able to utilise a wide range of starch sources, which indicated that the species had limited capability in using dietary carbohydrates from different botanical origins. In conclusion, taro could be recommended as a potential starch to replace corn starch in the production of extruded feed for T.tambroides. A more detailed examination of the enzymes involved in the utilisation of different starches in T. tambroides could be carried out in future.

\section{Acknowledgments}

This study was funded by the Science, Technology and Innovation Ministry through the ScienceFund 04-01-04-SF1713 grant.

\section{References}

Abd-Aziz, S. (2002). Sago starch and its utilisation. Journal of Bioscience and Bioengineering, 94(6), 526-529.

Adamidou, S., Nengas, I., Alexis, M., Foundoulaki, E., Nikolopoulou, D., Campbell, P., Karacostas, I., Rigos, G., Bell, G. J., \& Jauncey, K. (2009).Apparent nutrient digestibility and gastrointestinal evacuation time in European seabass (Dicentrarchus labrax) fed diets containing different levels of legumes. Aquaculture, 289(1-2), 106112.

Ah-Hen, K., Lehnebach, G., Lemus-Mondaca, R., Zura-Bravo, L., Leyton, P., Vega-Gálvez, A., \& Figuerola, F. (2014). Evaluation of different starch sources in extruded feed for Atlantic salmon. Aquaculture Nutrition, 20(2), 183-191.

Al-Tameemi, R., Aldubaikul, A., \& Salman, N. A. (2010). Comparative study of $\alpha$-amylase activity in three Cyprinid species of different feeding habits from Southern Iraq. Turkish Journal of Fisheries and Aquatic Sciences, 10(3), 411-414.

Alonso, R., Aguirre, A., \& Marzo, F. (2000). Effects of extrusion and traditional processing methods on antinutrients and in vitro digestibility of protein and starch in faba and kidney beans. Food Chemistry, 68(2), 159-165.

Arnesen, P., \& Krogdahl, Å. (1993). Crude and pre-extruded products of wheat as nutrient sources in extruded diets for Atlantic salmon (Salmo salar, L) grown in sea water. Aquaculture, 118(1-2), 105-117.

AOAC. (1995). Association of Official Analytical Chemists. Official methods of analysis of AOAC International.

Ball, S., Guan, H. P., James, M., Myers, A., Keeling, P., Mouille, G., Buléon, A., Colonna, P., \& Preiss, J. (1996). From glycogen to amylopectin: A model for the biogenesis of the plant starch granule. Cell, 86(3), 349-352.

Bureau, D. P., Kaushik, S. J., \& Cho, C. Y. (2003). Bioenergetics. In Fish nutrition (pp. 1-59). Academic Press.

Cavalheiro, J. M. O., de Souza, E. O., \& Bora, P. S. (2007). Utilization of shrimp industry waste in the formulation of tilapia (Oreochromis niloticus Linnaeus) feed. Bioresource Technology, 98(3), 602606.

Couto, A., Peres, H., Oliva-Teles, A., \& Enes, P. (2016). Screening of nutrient digestibility, glycaemic response and gut morphology alterations in gilthead seabream (Sparus aurata) fed whole cereal meals. Aquaculture, 450, 31-37.

Couto, A., Peres, H., Oliva-Teles, A., \& Enes, P. (2017). Nutritional value of whole cereal meals for European sea bass (Dicentrarchus labrax) juveniles. Aquaculture, 473, 128134.

De Cruz, C. R., Kamarudin, M. S., Saad, C. R., \& Ramezani-Fard, E. (2015). Effects of extruder die temperature on the physical properties of extruded fish pellets containing taro and broken rice starch. Animal Feed Science and Technology, 199, 137-145. 
De Silva, S. S., \& Anderson, T. A. (1994). Fish Nutrition in Aquaculture (Vol. 1). Springer Science \& Business Media.

Deo, P. C., Tyagi, A. P., Taylor, M., Becker, D. K., \& Harding, R. M. (2009). Improving taro (Colocasia esculenta var. esculenta) production using biotechnological approaches. The South Pacific Journal of Natural and Applied Sciences, 27(1), 6-13.

Drewe, K. E., Horn, M. H., Dickson, K. A., \& Gawlicka, A. (2004). Insectivore to frugivore: Ontogenetic changes in gut morphology and digestive enzyme activity in the characid fish Brycon guatemalensis from Costa Rican rain forest streams. Journal of Fish Biology, 64(4), 890-902.

DOA. (2012) Sarawak Agriculture Statistics 2012, Department of Agriculture Sarawak, Kuching.

Do Carmo Gominho-Rosa, M., Rodrigues, A. P. O., Mattioni, B., de Francisco, A., Moraes, G., \& Fracalossi, D. M. (2015). Comparison between the omnivorous jundiá catfish (Rhamdia quelen) and Nile tilapia (Oreochromis niloticus) on the utilization of dietary starch sources: Digestibility, enzyme activity and starch microstructure. Aquaculture, 435, 92-99.

Enes, P., Panserat, S., Kaushik, S., \& Oliva-Teles, A. (2011). Dietary carbohydrate utilization by European sea bass (Dicentrarchus labrax L.) and gilthead sea bream (Sparus aurata L.) juveniles. Reviews in Fisheries Science, 19(3), 201-215.

FAO. (1998). Carbohydrates in human nutrition (FAO Food and Nutrition Paper 66). Rome, Italy: FAO.

FAO. (2017). FAOSTAT database. Food and Agriculture Organization of the United Nations, Rome, Italy: FAO.

Ferraro, V., Piccirillo, C., Tomlins, K., \& Pintado, M. E. (2016). Cassava (Manihot esculenta Crantz) and yam (Dioscorea spp.) crops and their derived foodstuffs: Safety, security and nutritional value. Critical Reviews in Food Science and Nutrition, 56(16), 2714-2727.

Gabriel, U. U., Akinrotimi, O. A., Bekibele, D. O., Onunkwo, D. N., \& Anyanwu, P. E. (2007). Locally produced fish feed: Potentials for aquaculture development in sub-Saharan Africa. African Journal of Agricultural Research, 2(7), 287-295.

Gatlin III, D. M., Barrows, F. T., Brown, P., Dabrowski, K., Gaylord, T. G., Hardy, R. W., Herman, E., Hu, G., Krogdahl, Å., Nelson, R., \& Overturf, K. (2007). Expanding the utilization of sustainable plant products in aquafeeds: A review. Aquaculture Research, 38(6), 551-579.

German, D. P., Nagle, B. C., Villeda, J. M., Ruiz, A. M., Thomson, A. W., Contreras Balderas, S., \& Evans, D. H. (2010). Evolution of herbivory in a carnivorous clade of minnows (Teleostei: Cyprinidae): Effects on gut size and digestive physiology. Physiological and Biochemical Zoology, 83(1), 1-18.

Ghavidel, R. A., \& Prakash, J. (2007). The impact of germination and dehulling on nutrients, antinutrients, in vitro iron and calcium bioavailability and in vitro starch and protein digestibility of some legume seeds. LWT-Food Science and Technology, 40(7), 1292-1299.

Glencross, B., Evans, D., Hawkins, W., \& Jones, B. (2004). Evaluation of dietary inclusion of yellow lupin (Lupinus luteus) kernel meal on the growth, feed utilisation and tissue histology of rainbow trout (Oncorhynchus mykiss). Aquaculture, 235(1-4), 411-422.

Glencross, B., Blyth, D., Tabrett, S., Bourne, N., Irvin, S., Anderson, M., Fox-Smith, T., \& Smullen, R. (2012). An assessment of cereal grains and other starch sources in diets for barramundi (Lates calcarifer) -implications for nutritional and functional qualities of extruded feeds. Aquaculture Nutrition, 18(4), 388-399.

Gu, M., Kortner, T. M., Penn, M., Hansen, A. K., \& Krogdahl, A. (2014). Effects 
of dietary plant meal and soya-saponin supplementation on intestinal and hepatic lipid droplet accumulation and lipoprotein and sterol metabolism in Atlantic salmon (Salmo salar L.). British Journal of Nutrition, 111(3), 432-444.

Guerreiro, I., Oliva-Teles, A., \& Enes, P. (2015). Improved glucose and lipid metabolism in European sea bass (Dicentrarchus labrax) fed short-chain fructooligosaccharides and xylooligosaccharides. Aquaculture, 441, 57-63.

Hamid, N. K. A., Mahayat, M., \& Hashim, R. (2011). Utilization of different carbohydrate sources and starch forms by bagrid catfish (Mystus nemurus)(Cuv \& Val). Aquaculture Nutrition, 17(2), e10-e18.

Hardy, R. W. (2002). Rainbow trout, Oncorhynchus mykiss. Nutrient Requirements and Feeding of Finfish for Aquaculture, 184-202.

Hardy, R. W., \& Barrows, F. T. (2003). Diet formulation and manufacture. In Fish Nutrition (pp. 505-600). Academic Press.

Hemre, G. I., \& Hansen, T. (1998). Utilisation of different dietary starch sources and tolerance to glucose loading in Atlantic salmon (Salmo salar), during parr -smolt transformation. Aquaculture, 161(1-4), $145-157$.

Hemre, G. I., Mommsen, T. P., \& Krogdahl, A. (2002). Carbohydrates in fish nutrition: Effects on growth, glucose metabolism and hepatic enzymes. Aquaculture Nutrition, 8(3), 175-194.

Hilton, J. W., Cho, C. Y., \& Slinger, S. J. (1981). Effect of extrusion processing and steam pelleting diets on pellet durability, pellet water absorption, and the physiological response of rainbow trout (Salmo gairdneri R.). Aquaculture, 25(2-3), 185-194.

Hung, L. T., Lazard, J., Mariojouls, C., \& Moreau, Y. (2003). Comparison of starch utilization in fingerlings of two Asian catfishes from the Mekong River
(Pangasius bocourti Sauvage, 1880, Pangasius hypophthalmus Sauvage, 1878). Aquaculture Nutrition, 9(4), 215222.

Ishak, S. D., Kamarudin, M. S., Ramezani-Fard, E., Saad, C. R., \& Yusof, Y.A. (2016). Effects of varying dietary carbohydrate levels on growth performance, body composition and liver histology of Malaysian mahseer fingerlings (Tor tambroides). Journal of Environmental Biology, 37, 755-764.

Islam, M. S., \& Tanaka, M. (2004). Optimization of dietary protein requirement for pondreared mahseer Tor putitora Hamilton (Cypriniformes: Cyprinidae). Aquaculture Research, 35(13), 1270-1276.

Ismail, S., Kamarudin, M. S., \& RamezaniFard, E. (2012) Performance of commercial poultry offal meal as fishmeal replacement in the diet of juvenile Malaysian mahseer, Tor tambroides. Asian Journal of Animal and Veterinary Advances, 8(2), 284-292.

Kamalam, B. S., Medale, F., \& Panserat, S. (2017). Utilisation of dietary carbohydrates in farmed fishes: New insights on influencing factors, biological limitations and future strategies. Aquaculture, 467, 3-27.

Kamarudin, M. S., Ishak, S. D., Ramezani-Fard, E., Saad, C. R., \& Yusof, Y. A. (2016). Effects of different temperature profiles and corn-sago starch ratios on physical properties of extruded tilapia diets. Iranian Journal of Fisheries Sciences, 15(2), 715726.

Kannadhason, S., Muthukumarappan, K., \& Rosentrater, K. A. (2009). Effects of ingredients and extrusion parameters on aquafeeds containing DDGS and tapioca starch. Journal of Aquaculture Feed Science and Nutrition, 1(1), 6-21.

Kannadhason, S., Muthukumarappan, K., \& Rosentrater, K. A. (2011). Effect of starch sources and protein content on extruded aquaculture feed containing DDGS. Food and Bioprocess Technology, 4(2), 282-294. 
Keetels, C. J. A. M., Oostergetel, G. T., \& Van Vliet, T. (1996). Recrystallization of amylopectin in concentrated starch gels. Carbohydrate Polymers, 30(1), 61-64.

Keramat-Amirkolaie, A. (2013). The effect of feed ingredients on the settling velocity of feces in tilapia (Oreochromis niloticus L.). Iranian Journal of Fisheries Sciences, 12(2), 484-489.

Krogdahl, Å., Hemre, G. I., \& Mommsen, T. P. (2005). Carbohydrates in fish nutrition: Digestion and absorption in postlarval stages. Aquaculture Nutrition, 11(2), 103122 .

Lone, A., \& Lone, S. (2014). Effects of dietary protein levels on growth, feed utilization, protein retention efficiency of Tor tor (Hamilton 1822). Journal of Aquaculture Feed Science and Nutrition, 6, 1-5.

Luna, L. G. (1968). Manual of Histologic Staining Method of the Armed Forces Institute of Pathology. New York: McGrawHill Book Company.

Manners, D. J. (1989). Recent developments in our understanding of amylopectin structure. Carbohydrate Polymers, 11(2), 87-112.

Mohanta, K. N., Mohanty, S. N., \& Jena, A. J. (2007). Protein-sparing effect of carbohydrate in silver barb, Puntius gonionotus fry. Aquaculture Nutrition, 13(4), 311-317.

Murai, T., Sumalangkay, A., \& Pascual, F. P. (1981). The water stability of shrimp diets with various polysaccharides as a binding agent. SEAFDEC Aquaculture Department Quarterly Research Report, 5(2), 18-20.

NRC. (2011). National Research Council. Nutrient requirements of fish and shrimp. National Academies Press.

Ng, W. K., \& Andin, V. C. (2011). The Malaysian mahseer, Tor tambroides (Bleeker), requires low dietary lipid levels with a preference for lipid sources with high omega-6 and low omega-3 polyunsaturated fatty acids. Aquaculture, 322, 82-90.

Onwueme, I. (1999). Taro cultivation in Asia and the Pacific. FAO: Regional Office for Asia and the Pacific (RAP) Publication, 16, 1-9.

Pascual, F. P., \& Sumalangcay, A. (1981). Gum arabic, carrageenan of various types and sago palm starch as binders in prawn diets. SEAFDEC Aquaculture Department Quarterly Research Report, 5(4), 11-15.

Piedad-Pascual, F., Bandonil, L., \& Destajo, W. H. (1978). The effect of different binders on the water stability of feeds for prawn. SEAFDEC Aquaculture Department Quarterly Research Report, 2(1), 31-35.

Pfister, B., \& Zeeman, S. C. (2016). Formation of starch in plant cells. Cellular and Molecular Life Sciences, 73(14), 2781-2807.

Rathod, R. P., \& Annapure, U. S. (2016). Effect of extrusion process on antinutritional factors and protein and starch digestibility of lentil splits. LWT-Food Science and Technology, 66, 114-123.

Ramezani-Fard, E., Kamarudin, M. S., Harmin, S. A., \& Saad, C. R. (2012). Dietary saturated and omega-3 fatty acids affect growth and fatty acid profiles of Malaysian Mahseer. European Journal of Lipid Science and Technology, 114(2), 185-193.

Ramezani Fard, E., Salleh Kamarudin, M., Ehteshami, F., Shakiba Zadeh, S. H., Roos Saad, C., \& Zokaeifar, H. (2014). Effect of dietary linolenic acid (18: 3n -3)/ linoleic acid (18: $2 n-6)$ ratio on growth performance, tissue fatty acid profile and histological alterations in the liver of juvenile Tor tambroides. Iranian Journal of Fisheries Sciences, 13(1), 185-200.

Rosentrater, K. A., Muthukumarappan, K., \& Kannadhason, S. (2009). Effects of ingredients and extrusion parameters on properties of aquafeeds containing DDGS and corn starch. Journal of Aquaculture Feed Science and Nutrition, 1(2), 44-60. 
Russell, P. M., Davies, S. J., Gouveia, A., \& Tekinay, A. A. (2001). Influence of dietary starch source on liver morphology in juvenile cultured European sea bass (Dicentrarchus labrax L.). Aquaculture Research, 32, 306-314.

Singh, J., Kaur, L., \& McCarthy, O. J. (2007). Factors influencing the physico-chemical, morphological, thermal and rheological properties of some chemically modified starches for food applications-A review. Food Hydrocolloids, 21(1), 1-22.

Song, M. Q., Shi, C. M., Lin, S. M., Chen, Y. J., Shen, H. M., \& Luo, L. (2018). Effect of starch sources on growth, hepatic glucose metabolism and antioxidant capacity in juvenile largemouth bass, Micropterus salmoides. Aquaculture, 490, 355-361.

Sørensen, M. L. K. S. T., Ljøkjel, K., Storebakken, T., Shearer, K. D., \& Skrede, A. (2002). Apparent digestibility of protein, amino acids and energy in rainbow trout (Oncorhynchus mykiss) fed a fish meal based diet extruded at different temperatures. Aquaculture, 211(1-4), 215225.

Sørensen, M. (2012). A review of the effects of ingredient composition and processing conditions on the physical qualities of extruded high-energy fish feed as measured by prevailing methods. Aquaculture Nutrition, 18(3), 233-248.

Storebakken, T., Shearer, K. D., Baeverfjord, G., Nielsen, B. G., Åsgård, T., Scott, T., \& De Laporte, A. (2000). Digestibility of macronutrients, energy and amino acids, absorption of elements and absence of intestinal enteritis in Atlantic salmon, Salmo salar, fed diets with wheat gluten. Aquaculture, 184(1-2), 115-132.
Tan, E. S. (1980). Some aspects of the biology of Malaysian riverine cyprinids. Aquaculture, 20(3), 281-289.

Trushenski, J. T., Kasper, C. S., \& Kohler, C. C. (2006). Challenges and opportunities in finfish nutrition. North American Journal of Aquaculture, 68(2), 122-140.

Ufodike, E. B. C., \& Matty, A. J. (1983). Growth responses and nutrient digestibility in mirror carp (Cyprinus carpio) fed different levels of cassava and rice. Aquaculture, 31(1), 4150 .

Umar, S., Kamarudin, M. S., \& RamezaniFard, E. (2013). Physical properties of extruded aquafeed with a combination of sago and tapioca starches at different moisture contents. Animal Feed Science and Technology, 183, 51-55.

Venou, B., Alexis, M. N., Fountoulaki, E., Nengas, I., Apostolopoulou, M., \& Castritsi-Cathariou, I. (2003). Effect of extrusion of wheat and corn on gilthead sea bream (Sparus aurata) growth, nutrient utilization efficiency, rates of gastric evacuation and digestive enzyme activities. Aquaculture, 225(1-4), 207-223.

Wilson, R. P. (1994). Utilization of dietary carbohydrate by fish. Aquaculture, 124(14), 67-80.

Wu, X. Y., Liu, Y. J., Tian, L. X., Mai, K. S., \& Yang, H. J. (2007). Utilization of different raw and pre-gelatinized starch sources by juvenile yellowfin seabream Sparus latus. Aquaculture Nutrition, 13(5), 389-396.

Wu, X., Castillo, S., Rosales, M., Burns, A., Mendoza, M., \& Gatlin III, D. M. (2015). Relative use of dietary carbohydrate, nonessential amino acids, and lipids for energy by hybrid striped bass, Morone chrysops 9 $\times$ M. saxatilis ${ }^{\hat{D}}$. Aquaculture, 435, 116-119. 